\title{
Effect of Fly Ash and Water in Hydrated Srpc-A Ftir Study
}

\author{
K.Thiruppathi \\ Department of Physics, AMET University \\ Chennai, TamilNadu, India \\ E-mail: thiruraj_ka@rediffmail.com \\ S.Barathan (Corresponding author) \\ Department of Physics, Annamalai University \\ Annamalainagar 608 002, Tamilnadu, India \\ E-mail: sbarathan_au@rediffmail.com \\ N.Anandhan \\ Department of Physics, SRM University \\ Chennai, 603 203, Tamilnadu, India \\ E-mail: anandhan_kn@rediffmail.com \\ G.Sivakumar \\ Department of Physics, Annamalai University \\ Annamalainagar 608 002, Tamilnadu, India \\ E-mail: gsk_cisl@yahoo.com
}

\begin{abstract}
The present investigation, deals with the study of both hydrated Sulfate Resisting Portland Cement (SRPC) and fly ash (fly ash 20\%,30\% and 50\%) composite with two different waters. Among the three percentages of fly ash addition, 30\% addition is found to be optimum. The samples (SRPC and 30\% fly ash) were analyzed using the Fourier Transform Infrared Spectroscopy (FTIR) spectra. The relationship between compressive strength and molecular vibration changes were discussed using FTIR spectra. Also, the setting time is identified with the FTIR spectra and proper explanation with available literature for the kinetics is presented. It is inferred that increasing the fly ash concentration reduce the setting time. This is due to the calcium sulfoaluminate (CSA) present in the fly ash. Result of this study indicates that the blended paste better perform than the control paste hydrated with distilled water and effluent water.
\end{abstract}

Keywords: Fly ash, Cement, FTIR, Hydration, Setting

\section{Introduction}

Cement is an energy-intensive component of concrete. The unit cost of concrete can be reduced either by addition or partial replacement of cement with fly ash (Rafat Siddique, 2004). Recently the use of fly ash has dramatically increased due to an increase in environmental awareness and durability. 
The ASTM C 595 define pozzolan as, "a silicious or silicious and aluminous materials, which itself possess little or no cementitious value, but will, in finely divided form and in the presence of moisture, chemically react with $\mathrm{Ca}(\mathrm{OH})_{2}$ at ordinary temperature to form compounds possessing cementitious properties (pozzolanic activity)". Fly ashes mainly consist of $\mathrm{SiO}_{2}, \mathrm{Al}_{2} \mathrm{O}_{3}, \mathrm{Fe}_{2} \mathrm{O}_{3}$ and $\mathrm{CaO}$ and some impurities. According to ASTM C 618, fly ash belongs to class $\mathrm{C}$ if $\left(\mathrm{SiO}_{2},+\mathrm{Al}_{2} \mathrm{O}_{3}+\mathrm{Fe}_{2} \mathrm{O}_{3}\right)>70 \%$. Usually class $\mathrm{C}$ fly ashes have a higher content of $\mathrm{CaO}$ and exhibit pozzolanic properties (Papadakis and Tsimas, 2002).

The variations in the property of the fly ash blended system through different concentrations under Indian condition are meager. Also the utility of the effluent water in the mixture is of considerable interest. The use of FTIR better characterize the amorphous and poorly crystalline phases that occur in the blended cement. Hence, the present study is aimed at in evaluating the performance of fly ash in blended cement paste using distilled water (DW) and Effluent water (EW) and finds the relationship between compressive strength and molecular vibrational changes.

\section{Materials and Methods}

ASTM Type V Sulfate Resisting Portland Cement (SRPC) and Fly ash (FA) collected from Neyveli Lignite Corporation, Neyveli, Tamil Nadu, India were used in this study and their chemical analysis are given below.

\begin{tabular}{lllllllllll} 
Composition $\mathrm{CaO} \mathrm{SiO}_{2}$ & $\mathbf{A l}_{2} \mathbf{O}_{3}$ & $\mathbf{F e}_{2} \mathbf{O}_{3}$ & $\mathbf{S O}_{3}$ & $\mathbf{M g O}$ & \multicolumn{2}{c}{$\mathbf{N a}_{2} \mathbf{O}$} & $\mathbf{K}_{2} \mathbf{O}$ & LOI Others \\
SRPC & 65.08 & 22.20 & 3.47 & 4.08 & 1.25 & 0.88 & 0.27 & 0.76 & 1.90 & 0.11 \\
Fly ash & 7.64 & 53.38 & 27.40 & 3.04 & 1.69 & 4.03 & 0.74 & 0.12 & 1.70 & 0.26
\end{tabular}

The fly ash was mixed with SRPC in 20\%, 30\% and 50\% quantity on weight addition basis. The control (SRPC) and blended samples (with fly ash) were hydrated with distilled water and effluent water in a water to solid ratio of (w/s) 0.4 at different intervals like 1 hour,setting times, 1day, 7days, 28days.

The pelletised sample with $\mathrm{KBr}$ was made use of for recording FTIR spectra (4000-400 $\left.\mathrm{cm}^{-1}\right)$ using Perkin Elmer-RX1 FTIR spectrometer available at Centralised Instrumentation and Service Laboratory (CISL), Annamalai University. Setting time and compressive strength of DW and EW pastes were carried out using ASTM C 191 and 109 procedure and the results are given in figure 1 and 2 (Lee and Van Deventer, 2002 and Natalaya Shannhan and Abla Zayed, 2007).

\section{Results and Discussion}

\subsection{Setting time and Compressive strength study}

Figure 1 and 2 shows the setting time and compressive strength of SRPC and fly ash composites (DW and EW). From the figure, the fly ash composite $(20 \%, 30 \%$ and $50 \%)$ has a shorter setting time than the SRPC. This is due to $\mathrm{C}_{4} \mathrm{~A}_{3} \mathrm{~S}$ which is responsible for producing more ettringite and erttringite to monosulfate conversion and also CSH gel. Hence strength of the paste at early age is increased. The result coincides well with the many observers (Malhotra and Ramezianpour, 1994, Raungrut Cheerarot and Chai Jaturapitakkul, 2004). The EW hydrated pastes have quick setting than DW due to the presence of accelerating ions in EW (Ghorab et al., 1990). The compressive strength of SRPC performs better than SRPC blend up to $7^{\text {th }}$ days of hydration. This suggests that fly ash do not contribute notably for early strength development of the cement system. The results after $28^{\text {th }}$ day indicate that there is a continuous and significant improvement in strength in the case of SRPC blend. This increase in strength may be due to the continuous production of CSH, the inert nature of fly ash particle and hence pozzolanic activity. The effluent water hydrated samples get an accelerating trend in early periods (up 7 days). At 28 days, the strength of EW control paste decreases whereas the strength of DW fly ash blend increases. From the result $30 \%$ fly ash blend gives a maximum compressive strength and hence it has been investigated through FTIR.

\subsection{FTIR study}

The spectra of Distilled water (DW) and effluent water (EW) hydrated Control (SRPC) and blended cement (SRPC+30\%FA) are shown in the Fig.3-6.

\subsubsection{DW Hydrated control}

In cement hydration, water, carbonate, sulphate and silicate are the major bands identified through FTIR.

- FTIR spectra of DW hydrated control are shown in figure 3. In 1 hour spectrum (Fig.3a), a medium intensity band around $3428 \mathrm{~cm}^{-1}$ and $1640 \mathrm{~cm}^{-1}$ may be assigned to the $v_{1}$ and $v_{2}$ water stretching and bending vibration respectively. A shoulder is emerging at $3640 \mathrm{~cm}^{-1}$ may be due to the formation of $\mathrm{Ca}(\mathrm{OH})_{2}$ (Abdul Aziz A Khalil, 1982). At $8^{\text {th }}$ hour (Fig.3b), the $v_{1}$ and $v_{2}$ water bands are having a stronger intensity with a shift to higher wave number around $3430 \mathrm{~cm}^{-1}$ and $1642 \mathrm{~cm}^{-1}$. The $\mathrm{Ca}(\mathrm{OH})_{2}$ peak is strong and sharp at $3640 \mathrm{~cm}^{-1}$. At 15 hour (Fig. $3 \mathrm{c}$ ) a growth in $v_{1}$ and $v_{2}$ bands and $\mathrm{Ca}(\mathrm{OH})_{2}$ are observed. As hydration time passes, the $\mathrm{Ca}(\mathrm{OH})_{2}$ peak increases in intensity up to $7^{\text {th }}$ day (Fig.3e) and there after a constant intensity is observed. The $v_{1}$ and $v_{2}$ bands have a broad and strong intensity up to $28^{\text {th }}$ day.

- In 1hour, a strong band near $1440 \mathrm{~cm}^{-1}$ is assigned to asymmetric stretching vibration of carbonate $\left(v_{3} \mathrm{CO}_{3}^{2-}\right)$ band. After 1hour (up to $7^{\text {th }}$ day), the $v_{3}$ band at $1440 \mathrm{~cm}^{-1}$ has an increasing intensity and a new peak is observed (1day) at $873 \mathrm{~cm}^{-1}$ 
due to out-of-plane bending vibration $\left(v_{4} \mathrm{CO}_{3}^{2-}\right)$ of carbonate. The carbonation reactions are rapid but later $\left(28^{\text {th }}\right.$ day $)$ almost constant (Van Gervan, 2004).

- In 1hour, a strong triplet band appearing between 1105 and $1137 \mathrm{~cm}^{-1}$ can be assigned to asymmetric stretching vibration of sulphate $\left(v_{3} \mathrm{SO}_{4}^{2-}\right)$. Also, a weak doublet observed in lower region (around $600 \mathrm{~cm}^{-1}$ and $670 \mathrm{~cm}^{-1}$ ) are due to in-plane bending $\left(v_{2} \mathrm{SO}_{4}^{2-}\right)$ and out-of-plane bending $\left(v_{4} \mathrm{SO}_{4}^{2-}\right)$ vibrations of sulphate (Rai and Singh, 2005). After 1hour (at 15 hour), the $v_{3}$ triplet merges to form a singlet at $1124 \mathrm{~cm}^{-1}$. As time passes $\left(28^{\text {th }}\right.$ day), the bands are absent. The changes suggest that the sulphate reaction is rapid between 1 hour and 1day.

- In 1 hour, a strong and broad band around $925 \mathrm{~cm}^{-1}$ is due to asymmetric stretching vibration $\left(\mathrm{v}_{3} \mathrm{SiO}_{4}^{4-}\right)$ of $\mathrm{C}_{3} \mathrm{~S}$ and a medium intensity peak observed at $846 \mathrm{~cm}^{-1}$ is due to $\mathrm{C}_{2} \mathrm{~S}$. In lower region a strong and sharp peak observed at $520 \mathrm{~cm}^{-1}$ is due to out-of-plane-bending $\left(v_{4} \mathrm{SiO}_{4}^{4-}\right)$ vibration of $\mathrm{C}_{2} \mathrm{~S}$ and a weak peak observed at $465 \mathrm{~cm}^{-1}$ is due to in-plane-bending $\left(v_{2} \mathrm{SiO}_{4}^{4-}\right.$ ) vibration of $\mathrm{C}_{3} \mathrm{~S}$ (Ghosh and Handoo, 1980, Mollah et al., 2000). At $15^{\text {th }}$ hour (Fig.3c), the band at $925 \mathrm{~cm}^{-1}$ shifts to higher wave number at $970 \mathrm{~cm}^{-1}$ which indicate control gets setting (Fig.1a) (Mollah et al., 1999). From 1 day spectrum (Fig.3d), the $v_{3}$ band grown stronger in intensity. At $28^{\text {th }}$ days (Fig. $\left.3 \mathrm{f}\right)$, the $v_{4}$ peak $\left(520 \mathrm{~cm}^{-1}\right)$ decreases whereas the $v_{2}$ peak $\left(465 \mathrm{~cm}^{-1}\right)$ increases in intensity. The relative intensity change between $v_{4}$ and $v_{2}$ peak is faster. It indicates that the silicate polimerization and control gets strength and well coincide with the strength observation (Fig.1b) (Mollah et al., 1999). As hydration time passes the $v_{4}$ peak is totally consumed at $180^{\text {th }}$ day. In $28^{\text {th }}$ day spectrum (Fig. $3 f$ ), the $v_{2}$ and $v_{3}$ band $\left(469\right.$ and $\left.990 \mathrm{~cm}^{-1}\right)$ has strong intensity.

\subsubsection{Hydrated FA Blends SRPC}

Comparing the figures 3-6, the hydration reaction of 30\%FA blends (Fig.4) and EW pastes (Figs.5 and 6) seems to be similar as that of DW control with a variation in reaction rate which are given below.

The strong and broad band (Fig.4a) observed at $1110 \mathrm{~cm}^{-1}$ and a small peak at $641 \mathrm{~cm}^{-1}$ are due to $v_{3} \mathrm{SiO}_{4}^{4-}$ and CSA stretching vibration of characteristic fly ash band (Benarchid et al., 2005 and Cheng Xin et al., 2001, Malhotra and Ramezanianpour, 1994). From $7^{\text {th }}$ day (Fig.4e), the $\mathrm{Ca}(\mathrm{OH})_{2}$ peak gets a decrease in intensity, which may be due to starting of pozzolanic reaction of fly ash. The $\mathrm{Ca}(\mathrm{OH})_{2}$ peak is totally consumed within $28^{\text {th }}$ day (Fig. $4 \mathrm{f}$ ) spectrum. The water bands $\left(v_{1}\right.$ and $\left.v_{2}\right)$ have a higher intensity up to $28^{\text {th }}$ day.

The carbonate bands are in increasing trend up to $7^{\text {th }}$ day (Fig.4e) and beyond the band reduce in intensity as time elapses. The sulphate bands $\left(v_{2}\right.$ and $\left.v_{4}\right)$ doublet merges to form a singlet exhibiting the setting of the blend. This result coincides with setting time observation (Fig.1b). After 1day (Fig. 4d), the $v_{2}$ and $v_{4}$ peaks has continuous decreasing in intensity similar as that of SRPC.

At $9^{\text {th }}$ hour the $v_{3}$ silicate band shifts to higher wave number with higher intensity than control. The characteristic fly ash band (at $1110 \mathrm{~cm}^{-1}$ ) gets a stronger intensity up to $7^{\text {th }}$ day (Fig.4e) spectrum. After $7^{\text {th }}$ day a decreasing trend in intensity is observed indicate the starting of fly ash's reaction. The relative intensity changes between $v_{4}$ and $v_{2}$ are also faster. In $28^{\text {th }}$ day, the $v_{2}$ and $v_{3}$ bands ( 465 and $990 \mathrm{~cm}^{-1}$ ) gets an increased intensity than control. This may be due to higher rate of pozzolanic reaction with packing effect which increases the strength (Fig.1b).

In effluent water hydrated control (Fig.5), the $v_{3}$ silicate band shifts from $925 \mathrm{~cm}^{-1}$ to higher wave number $985 \mathrm{~cm}^{-1}$ and is stronger in intensity and the relative intensity variation between $v_{4}$ and $v_{2}$ silicate are also faster than DW control at $7^{\text {th }}$ day (Fig.5d). It indicates that the control paste gets a faster setting and strength (Fig.2a). After $7^{\text {th }}$ day, the $v_{2}$ and $v_{3}$ silicate band has lesser intensity than (Fig.5d) DW control. This indicates that the EW control has a lesser strength than DW control and coincides with the compressive strength observation (Fig.2b).

In effluent water hydrated fly ash blend (Fig.6), the $v_{3}$ silicate band shifts to higher frequency with intensity lesser than EW control (1day to $7^{\text {th }}$ day) and also greater than DW fly ash blend. After $7^{\text {th }}$ day, the $v_{3}$ silicate band has a stronger intensity and the relative intensity changes between $v_{4}$ and $v_{2}$ band is faster than EW control.

\section{Discussion}

The sulphate band change indicate that the ettringite formation of the paste. It is indicative of early faster dissolution of gypsum and other alkali sulphates, and according to the equation (1).

$$
3 \mathrm{CaO} . \mathrm{Al}_{2} \mathrm{O}_{3}+3 \mathrm{CaSO}_{4} \cdot 2 \mathrm{H}_{2} \mathrm{O}+26 \mathrm{H}_{2} \mathrm{O} \rightarrow 3 \mathrm{CaO} . \mathrm{Al}_{2} \mathrm{O}_{3} \cdot 3 \mathrm{CaSO}_{4} \cdot 32 \mathrm{H}_{2} \mathrm{O}
$$

\section{(Ettringite)}

The shift of water bands (lower to higher wave number) indicates that conversion of ettringite to monosulphate (equation 2). 


$$
2\left(3 \mathrm{CaO} \cdot \mathrm{Al}_{2} \mathrm{O}_{3} \cdot \mathrm{CaSO}_{4} \cdot 12 \mathrm{H}_{2} \mathrm{O}\right)+\mathrm{Ca}^{2+}+\mathrm{SO}_{4}^{2-}+8 \mathrm{H}_{2} \mathrm{O} \quad \rightarrow
$$

(Monosulphate)

This is indication of the control paste being converted from plastic to hardened state and coincides with the setting time (Fig.1\&2) (Tong Liang and Yang Nantu, 1994). The shift of silicate band $\left(920\right.$ to $\left.975 \mathrm{~cm}^{-1}\right)$ indicates the formation of CSH and $\mathrm{Ca}(\mathrm{OH})_{2}$ (equation 3 and 4) (Puertas and Fernández-Jiménez, 2003).

$$
\begin{aligned}
& 2 \mathrm{Ca}_{3} \mathrm{SiO}_{5}+6 \mathrm{H}_{2} \mathrm{O} \rightarrow 3 \mathrm{CaO} .2 \mathrm{SiO}_{2 .} 3 \mathrm{H}_{2} \mathrm{O}+3 \mathrm{Ca}(\mathrm{OH})_{2} \\
&(\mathrm{CSH}-\mathrm{gel}) \\
& 2 \mathrm{Ca}_{2} \mathrm{SiO}_{4}+4 \mathrm{H}_{2} \mathrm{O} \rightarrow 3 \mathrm{CaO} . \mathrm{SiO}_{2 .} 3 \mathrm{H}_{2} \mathrm{O}+\mathrm{Ca}(\mathrm{OH})_{2}
\end{aligned}
$$

$30 \%$ fly ash composite (Fig.4f) has higher content of CSH due to the pozzolanic reaction. When fly ash is mixed with water, together with cement, it induces pozzolanic reaction, in which glass phase silica and alumina progressively react with $\mathrm{Ca}(\mathrm{OH})_{2}$, forming hydrates of $\mathrm{CSH}$ as given in eqn. 5 .

$$
2 \mathrm{SiO}_{2}+3 \mathrm{Ca}(\mathrm{OH})_{2} \rightarrow 3 \mathrm{CaO} .2 \mathrm{SiO}_{2} 3 \mathrm{H}_{2} \mathrm{O} \quad(\mathrm{CSH} \text { gel })
$$

The reduction in $\mathrm{Ca}(\mathrm{OH})_{2}$ with fly ash content, increases the $\mathrm{CSH}$ gel, are responsible for the formation of the structure of hardened cement. Therefore, in paste containing fly ash, the hydration of cement forms the hardened structure and the pozzolanic reaction of fly ash improves the structure, ensuring strength development at a longer time.

In effluent water control, the early hydration is accelerated due to chloride ions present in the $\mathrm{EW}$. The $\mathrm{Ca}(\mathrm{OH})_{2}$ content is slightly less after 7 day. It is due to the control paste had suffered sulphate, magnesium ions etc., attack. Consequently, brucite (eqn.6), and recrystallisation of gypsum, ettringite $\left(670 \mathrm{~cm}^{-1}\right)$ are also formed (Lee et al., 2005). It may cause the deterioration of the paste. Brucite is produced by the reaction with $\mathrm{Mg}^{2+}$ ions and $\mathrm{Ca}(\mathrm{OH})_{2}$.

$$
\mathrm{MgSO}_{4}+\mathrm{Ca}(\mathrm{OH})_{2}+2 \mathrm{H}_{2} \mathrm{O} \rightarrow \mathrm{Mg}(\mathrm{OH})_{2}+\mathrm{CaSO}_{4}+2 \mathrm{H}_{2} \mathrm{O}
$$

The effluent water hydrated fly ash (30\%) composite has higher strength than EW control paste. This result is well supported by the earlier reports of Sunil Kumar (2000) who showed that the blending fly ash in OPC has higher strength than control and increased resistance against sea water. This may be due to chloride ion diffusion of paste decreases with increasing replacement of OPC. The decrease may be attributed to change in pore size distribution, increasing CSH gel formation and increasing alumina level enabling more chloride to be fixed as Friedel's salt $\left(\mathrm{C}_{3} \mathrm{~A} \cdot \mathrm{CaCl}_{2} .10 \mathrm{H}_{2} \mathrm{O}\right)(\mathrm{Leng}$ et al., 2000). EW hydrated fly ash composite has lesser strength than DW hydrated fly ash blends composite but higher than EW control paste.

\section{Conclusion}

The EW control has faster setting because of the formation of higher amount of ettringite than DW control. Fly ash blend reduces cementitious materials and hence slow hydration and less strength at early periods. After $7^{\text {th }}$ day, pozzolanic activity of DW hydrated fly ash blend produces more amount of CSH than control. EW hydrated fly ash composite also has higher strength (28 days) than EW control. The 30\% fly ash is a suitable percentage against sulphate attack as well as strength gain in SRPC. Its seems that suitable addition of fly ash and reduction of chloride ions concentration may bring an equivalent paste that of SRPC both in character and strength.

\section{References}

Abdul Aziz A. Khalil. (1982). Infrared spectroscopic studies of the hydration products of the system $\mathrm{CaO}-\mathrm{Al}_{2} \mathrm{O}_{3}-\mathrm{CaSO}_{4}-\mathrm{SiO}_{2}$. Cem. Concr. Res., 12:21-24.

Benarchid, My.Y., J. Rogez, A. Diouri, A. Boukhari and J. Aride. (2005). Formation and hydraulic behavior of chromium-phosphorus doped calcium sulfoaluminate cement. Thermochimica Acta, 433, 183-186.

Cheng Xin, Chang Jun, Lu Ling Chao, Liu Futian and Teng Bing. (2001). Study of Ba-bearing calcium sulphoaluminate minerals and cement. Cem. Concr. Res., 30, 77-81.

Ghorab, H.Y., M.S. Hilal and A.Antal. (1990). Effect of mixing and curing waters on the behavior of cement pastes and concrete. Part2: properties of cement paste and concrete. Cem. Concr. Res., 20:69-72.

Ghosh, S.N and S.K. Handoo. (1980). Infrared and Raman spectral studies in cement and concrete (review). Cem. Concr. Res., 10: 771-782.

Lee, S.T., H.Y. Moon and R.N. Swamy. (2005). Sulphate attack and role of silica fume in resisting strength loss. Cem. Concr.Compo., 27:65-76.

Lee, W.K.W and J.S.J. Van Deventer. (2002). The effect of ionic contaminants on the early age properties of alkali-activated flyash-based cements. Cem. Concr.Res., 32: 577-584. 
Leng, F., N. Feng and X.Liu. (2000). An experimental study on the properties of resistance to diffusion of chloride ions of flyash and blast furnace slag concrete. Cem. Concr. Res., 30(6):989-992.

Malhotra, V.M. and A.A. Ramezanianpour. (1994). Fly ash in Concrete, CANMET, second Edition, Canada.

Mollah, M.Y.A., Felix Lu, Robert Schennach and D.L.Cocke. (1999). An XRD, FTIR and SEM/EDS investigation of the effect of sodium lignosulfonate super plasticizer on the hydration of the hydration of Portland cement type V. Polym.-Plast. Technol. Eng., 38(5):849-868.

Mollah, M.Y.A., Wenhong Yu, Robert Schennach and D.L.Coke. (2000). FTIR spectroscopic investigation of the early hydration of Portland cement and the influence of sodium lignosulfonate. Cem. Concr. Res., 30:267-273.

Natalaya Shannhan and Abla Zayed. (2007). Cement composition and sulfate attack, Cem. Concr. Res., 37: 618-623.

Papadakis, V.G and S.Tsimas. (2002). Supplementary cementing materials in concrete part 1: efficiency and design. Cem. Concr. Res., 32: 1525-1532.

Puertas, F and A. Fernández-Jiménez. (2003). Mineralogical and microstructral characterization of alkali-activated flyash/slag pastes. Cem. Concr. Compo., 25: 287-292.

Rafat Siddique. (2004). Performance characteristics of high volume class F flyash concrete. Cem. Concr. Res., 34: 487-493.

Rai, U.S and R.K.Singh. (2005). Effect of polycrylamide on the different properties of cement and mortar. Mater. Sci. and Eng. A., 392:42-50.

Raungrut Cheerarot and Chai Jaturapitakkul. (2004). A study of disposed fly ash from landfill to replace Portland cement. Waste Management, 24: 701- 709.

Sunil Kumar. (2000). Influence of water quality on the strength of plain and blended cement concrete in marine environments. Cem. Concr. Res., 30:345-350.

Tong Liang and Yang Nantu. (1994). Hydration products of calcium sulfoaluminate in the presence of gypsum. Cem. Concr. Res., 24:150-158.

Van Gervan,T., Johnny Moors, Veroniek Dutre and Carlo Vandecasteele. (2004). Effect of $\mathrm{CO}_{2}$ on leaching from a cement stabilized MSWI flyash. Cem. Concr. Res., 34:1103-1109.
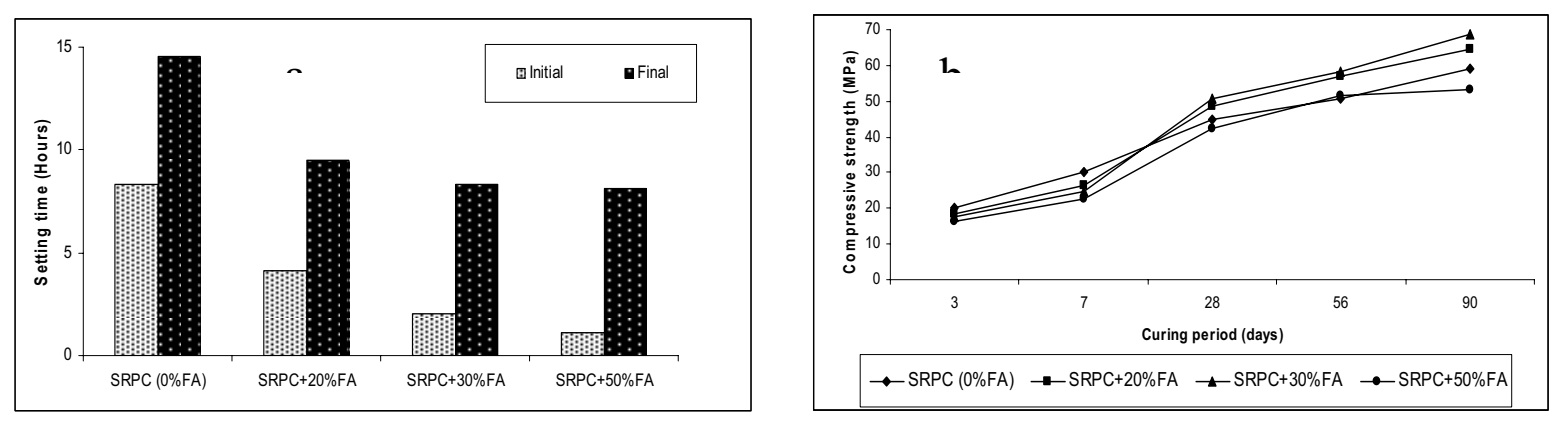

Figure 1. (a) Setting time and (b) Compressive strength of DW-Control and blended SRPC
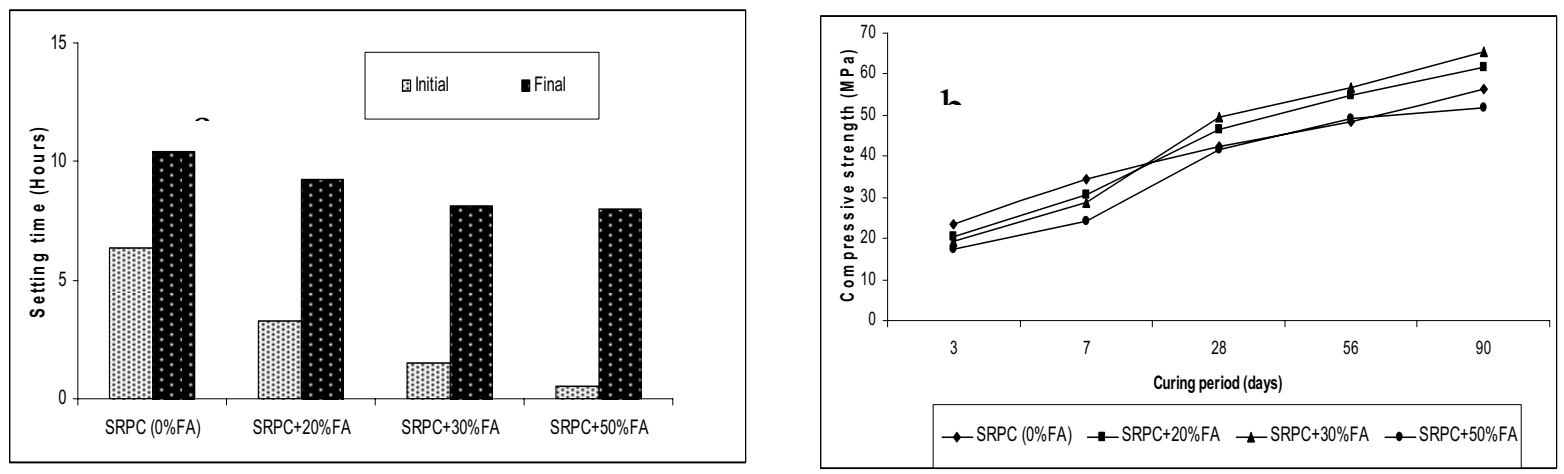

Figure 2. (a) Setting time and (b) Compressive strength of EW-Control and blended SRPC 


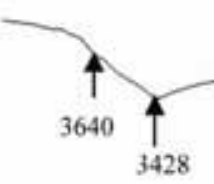

a

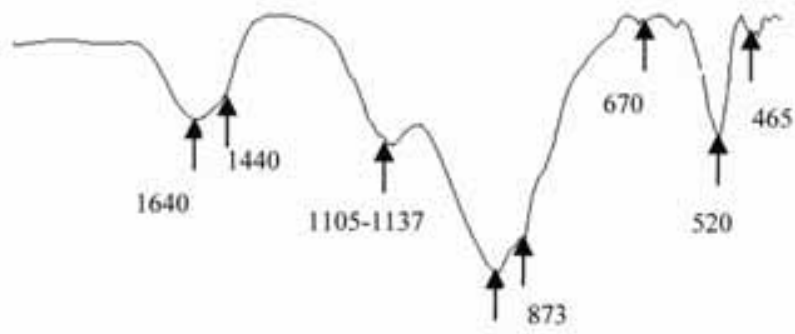

b
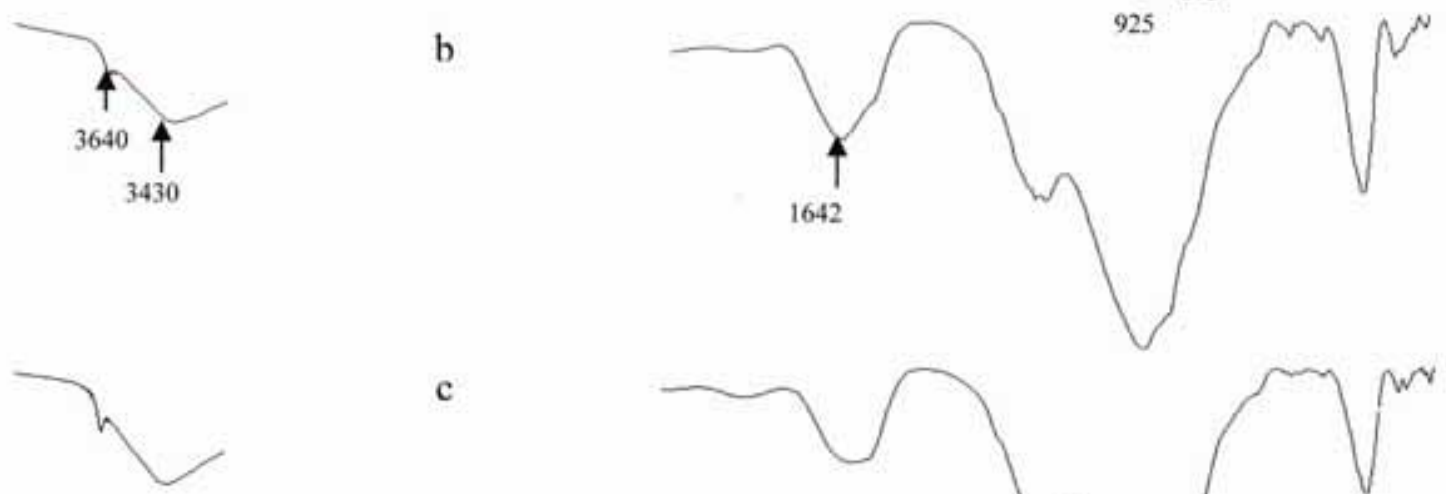

c
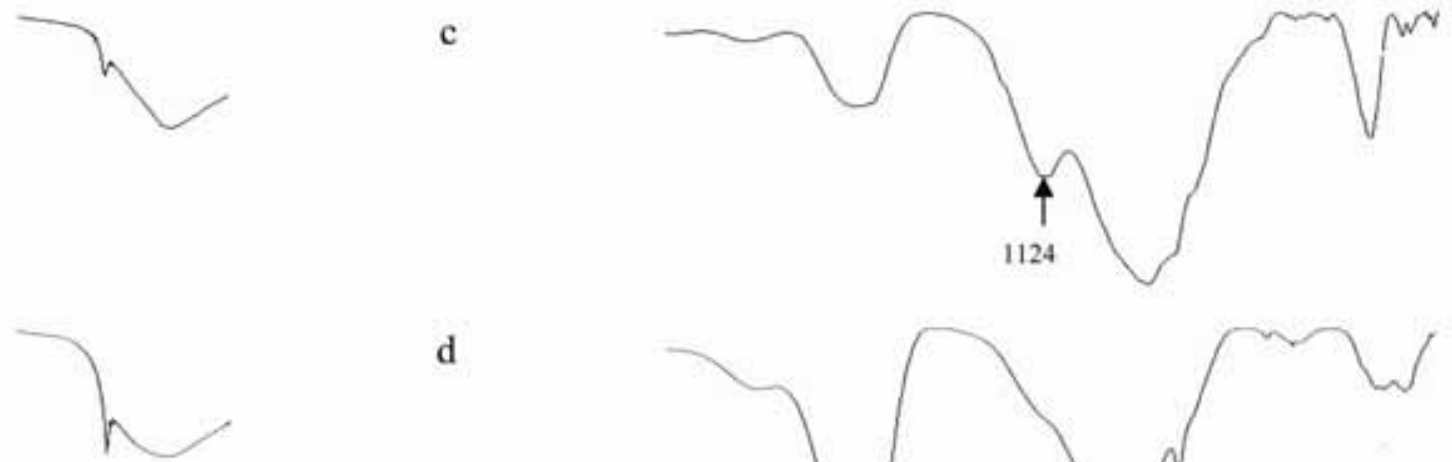

d
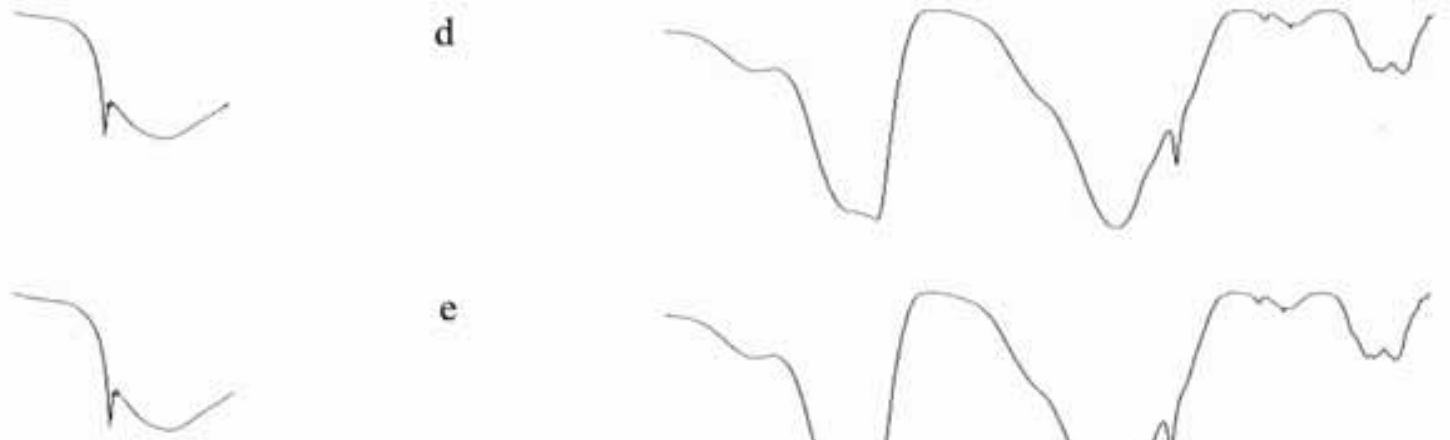

e
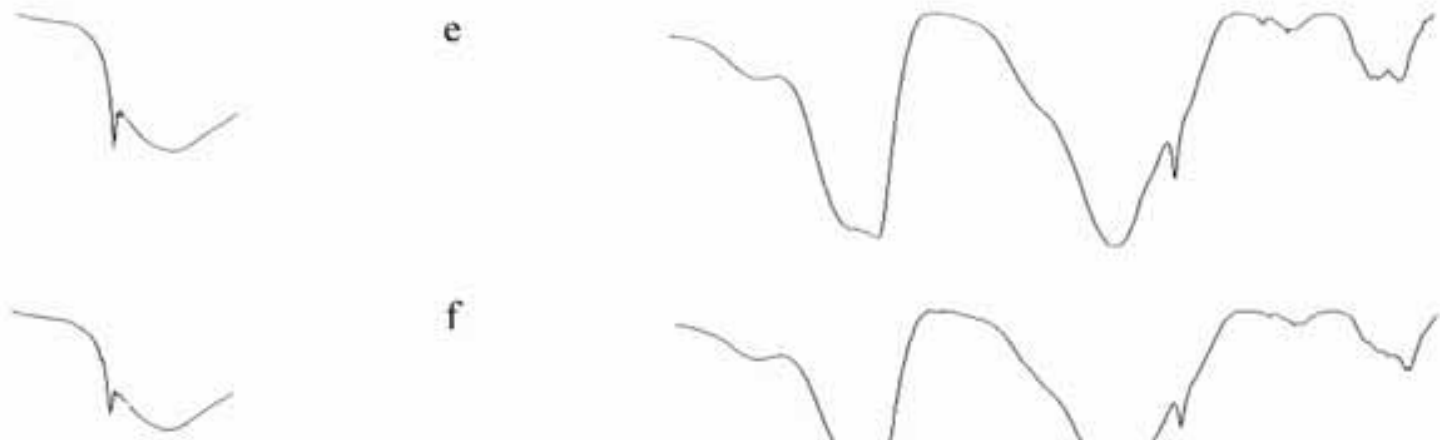

f
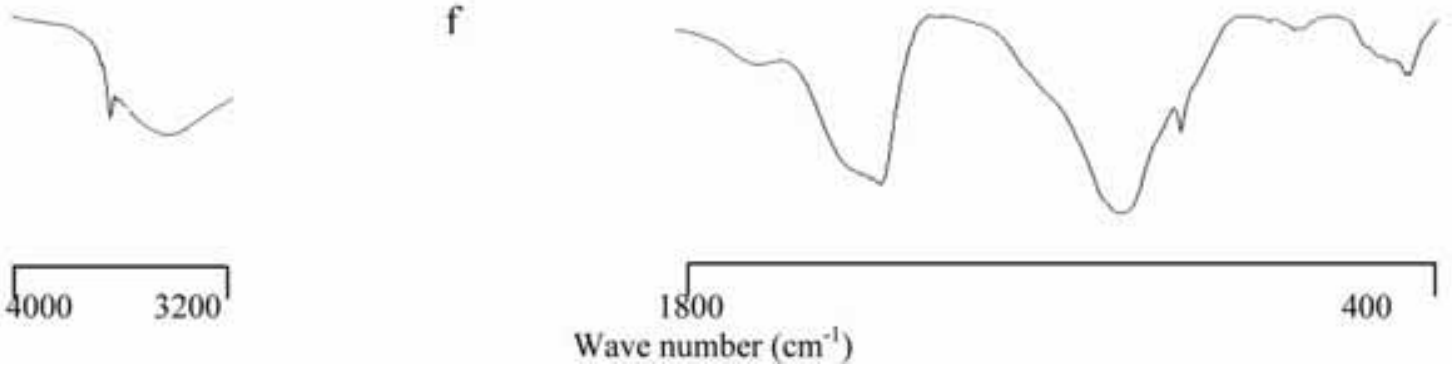

Figure 3. FTIR spectra of SRPC hydrated with DW for (a) 1 hour (b) 8 hours (c) 15 hours (d) 1 day (e) 7 days (f) 28 days 


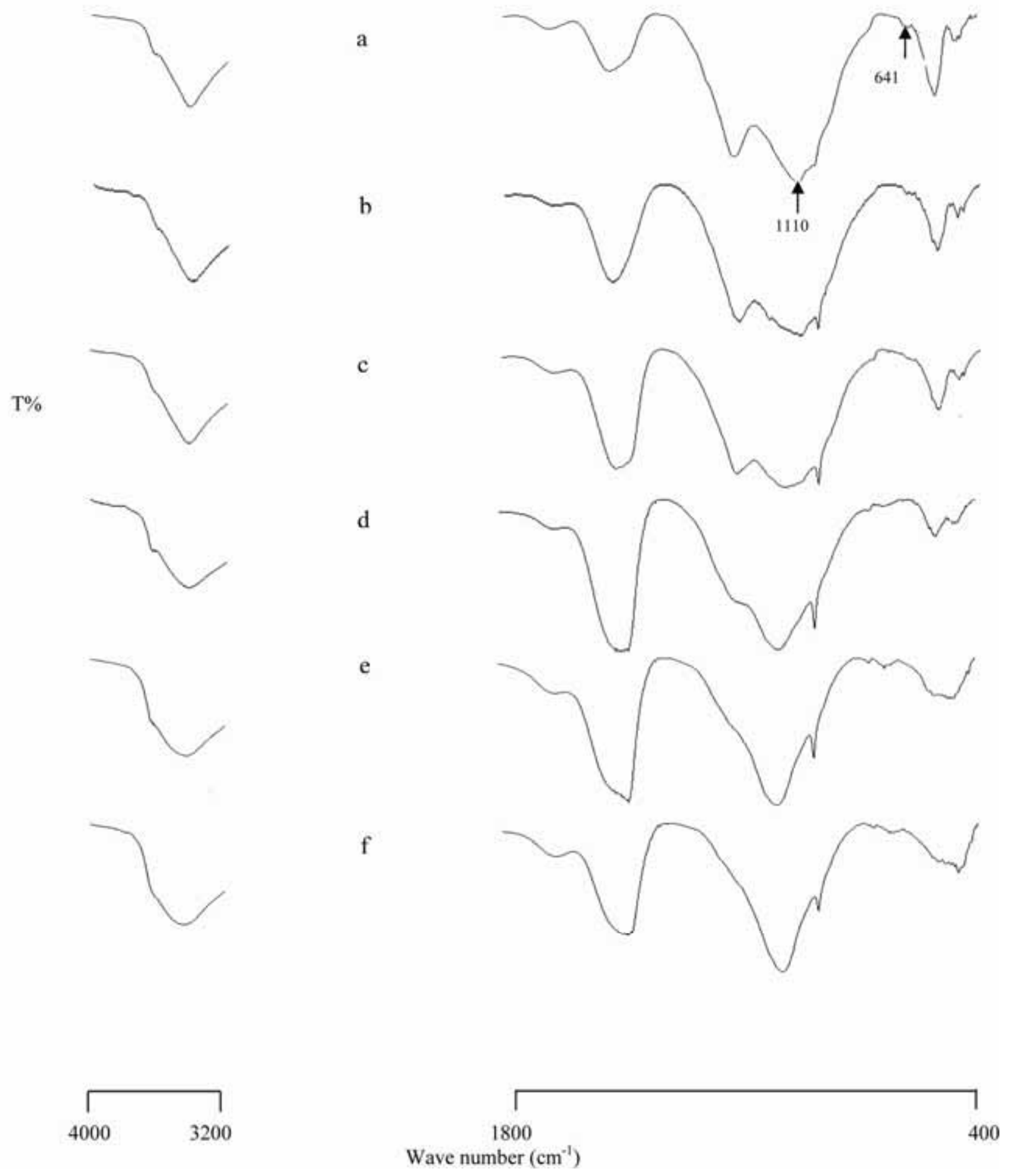

Figure 4. FTIR spectra of SRPC $+30 \%$ FA hydrated with DW for (a) 1 hour (b) 2 hours (c) 9 hours (d) 1 day (e) 7 days (f) 28 days 


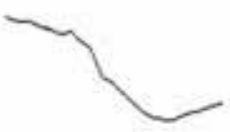

a

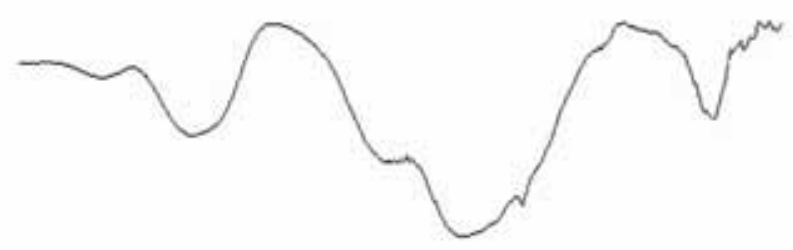

b

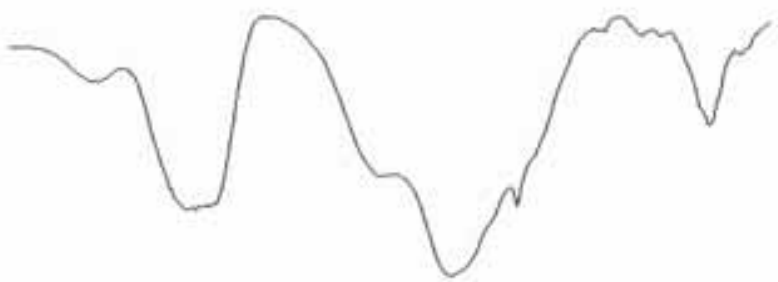

c
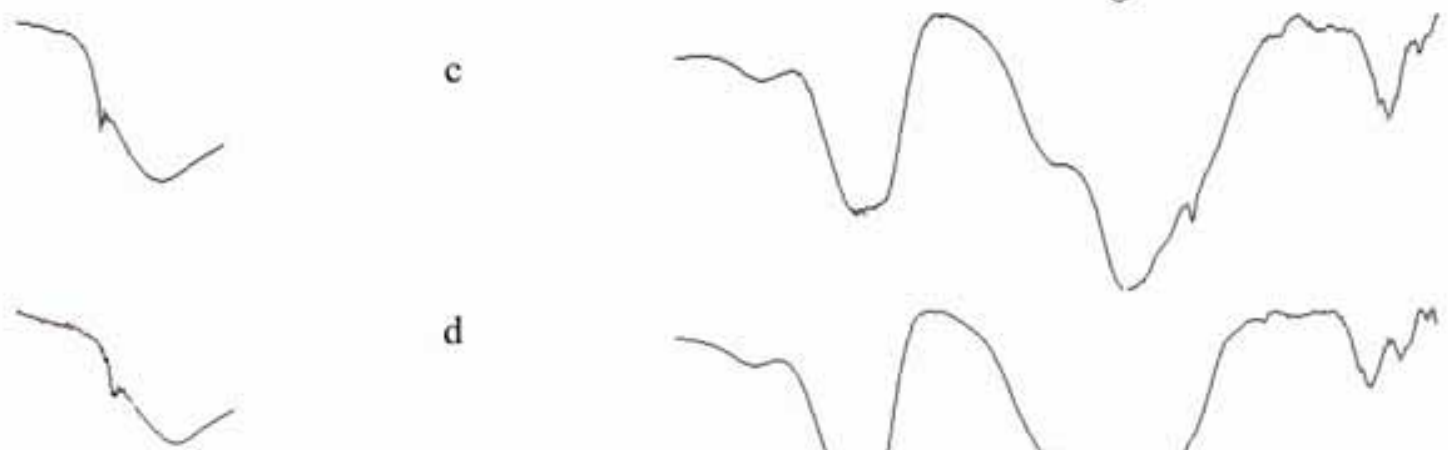

d

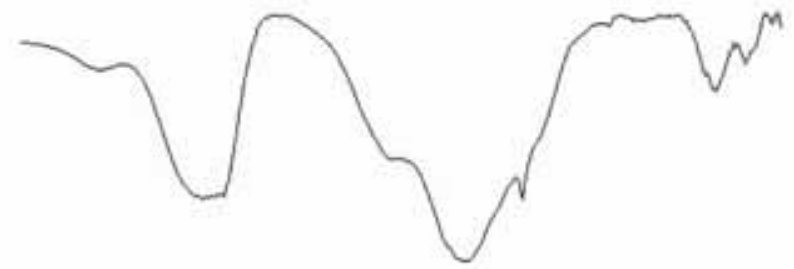

e
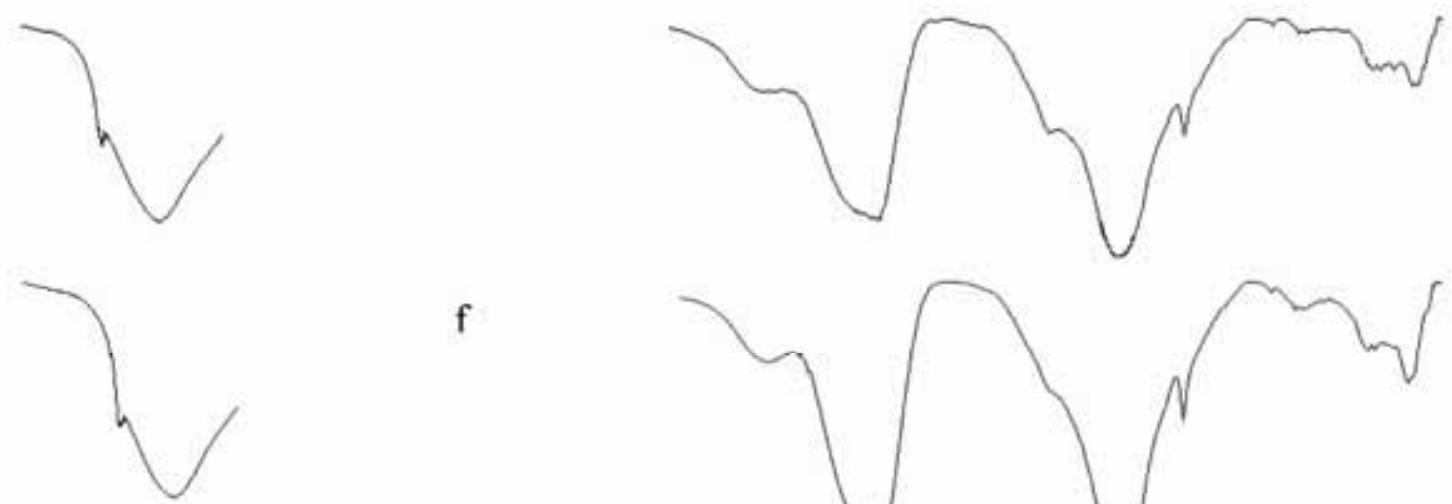

f

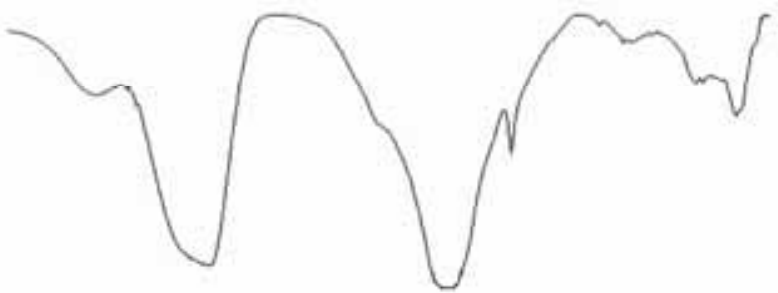

1800

Wave number $\left(\mathrm{cm}^{-1}\right)$
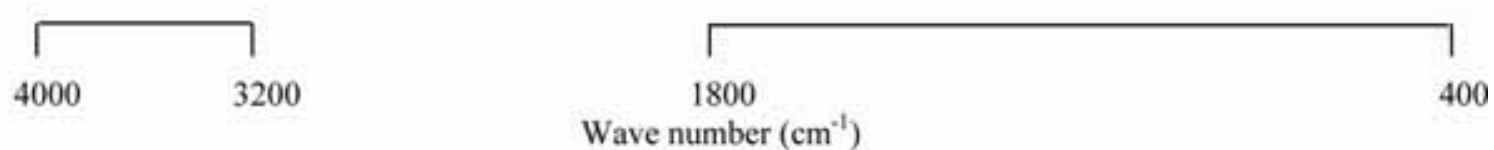

Figure 5. FTIR spectra of SRPC hydrated with EW for (a) 1 hour (b) 6 hours (c) 11 hours (d) 1 day (e) 7 days (f) 28 days 

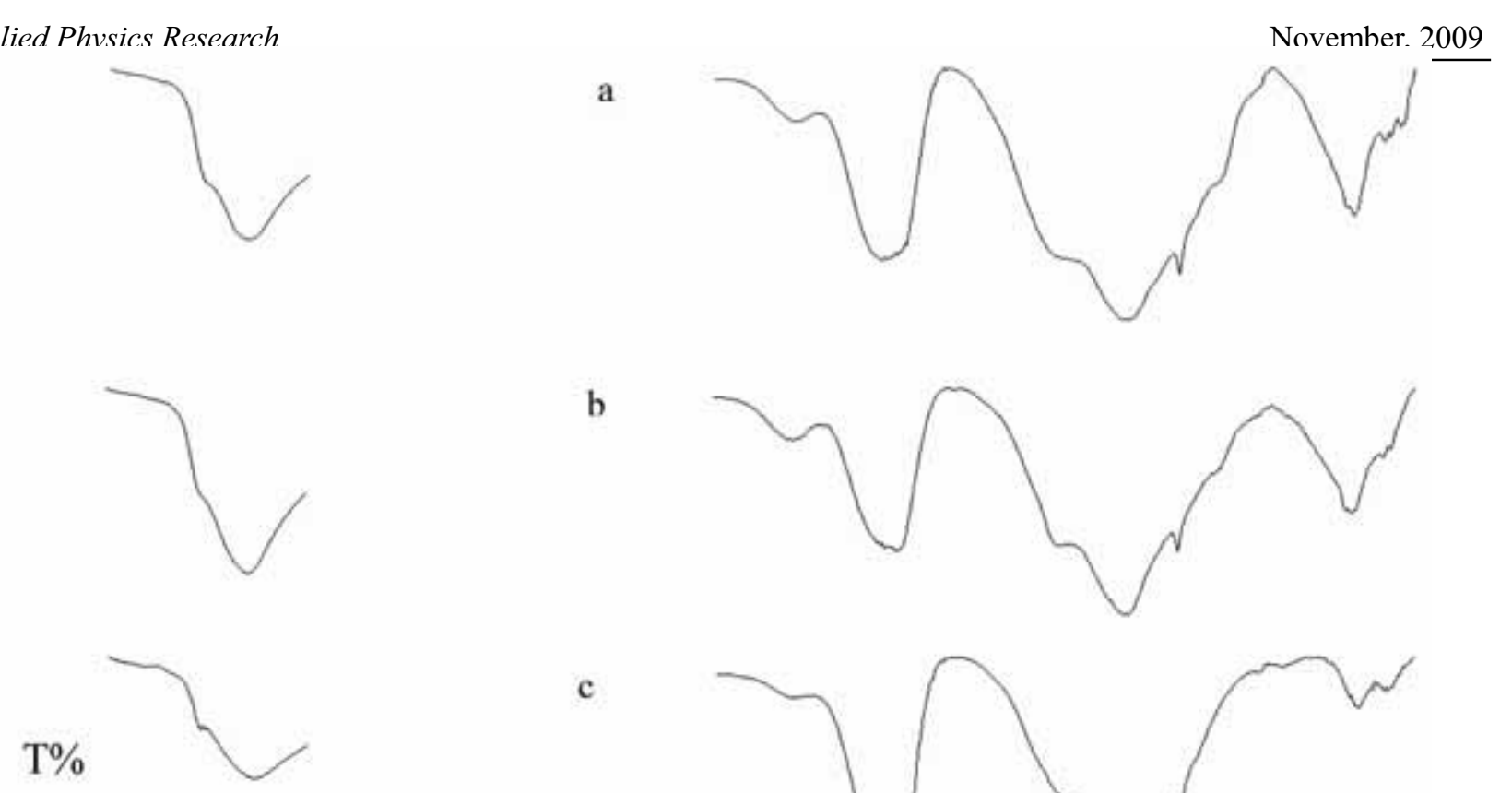

b

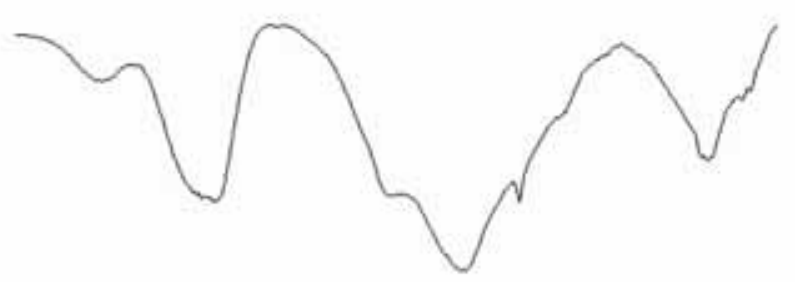

c
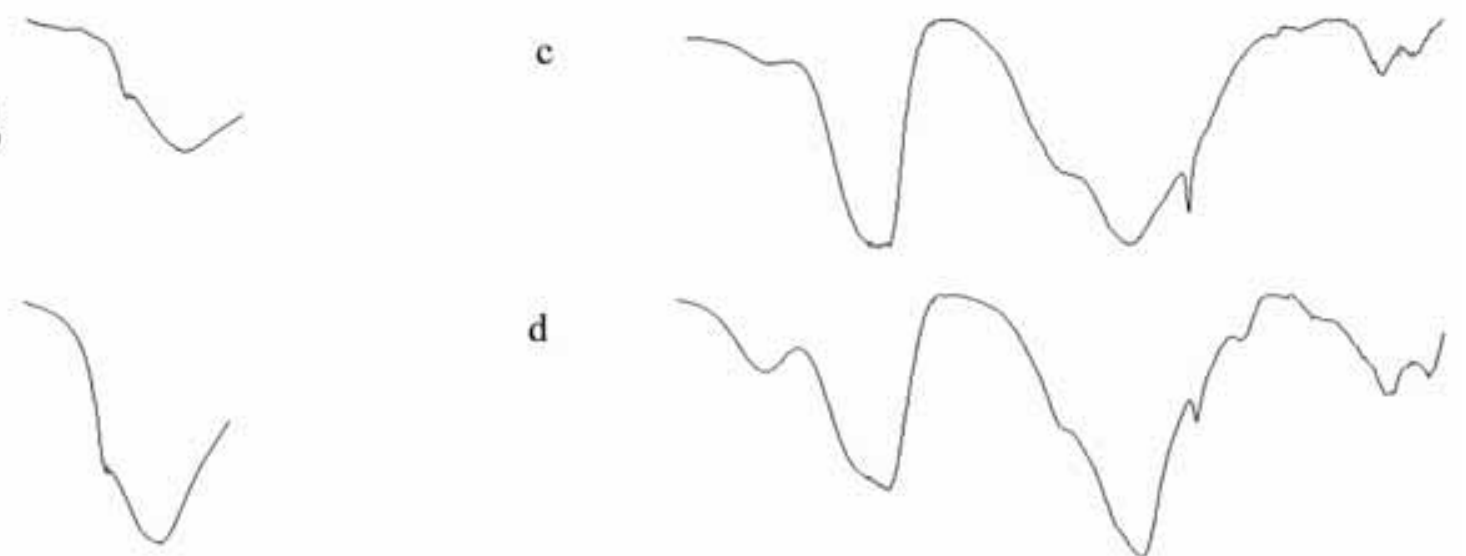

d
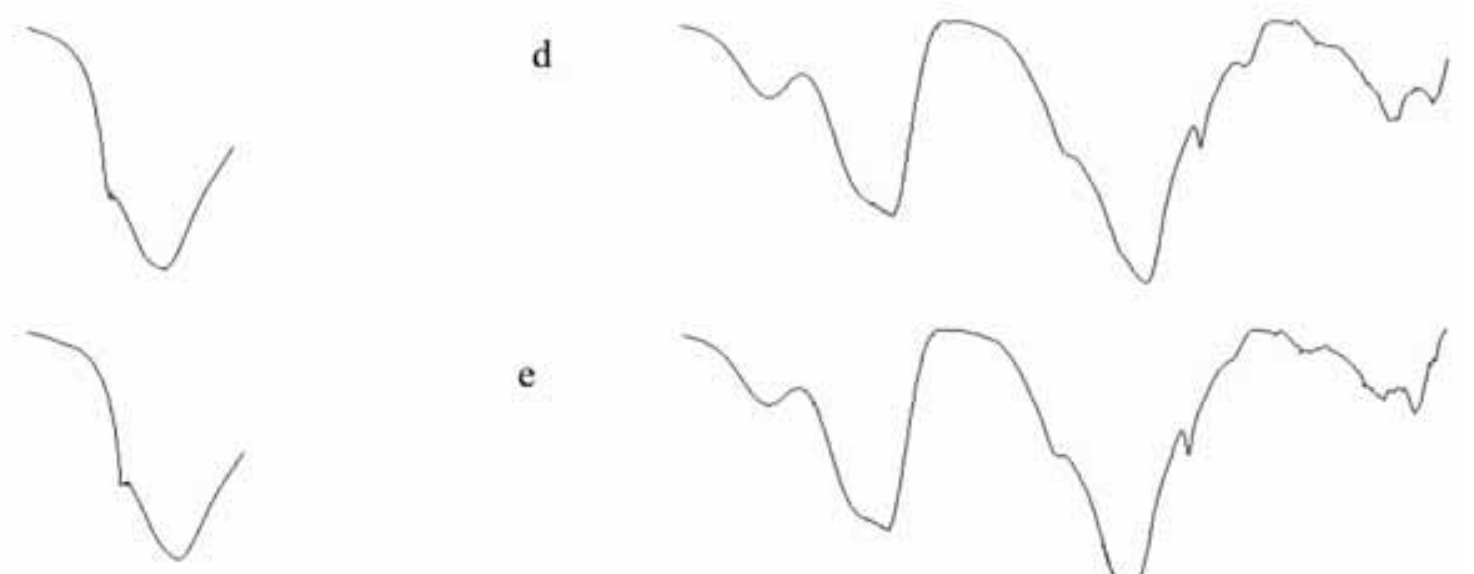

e
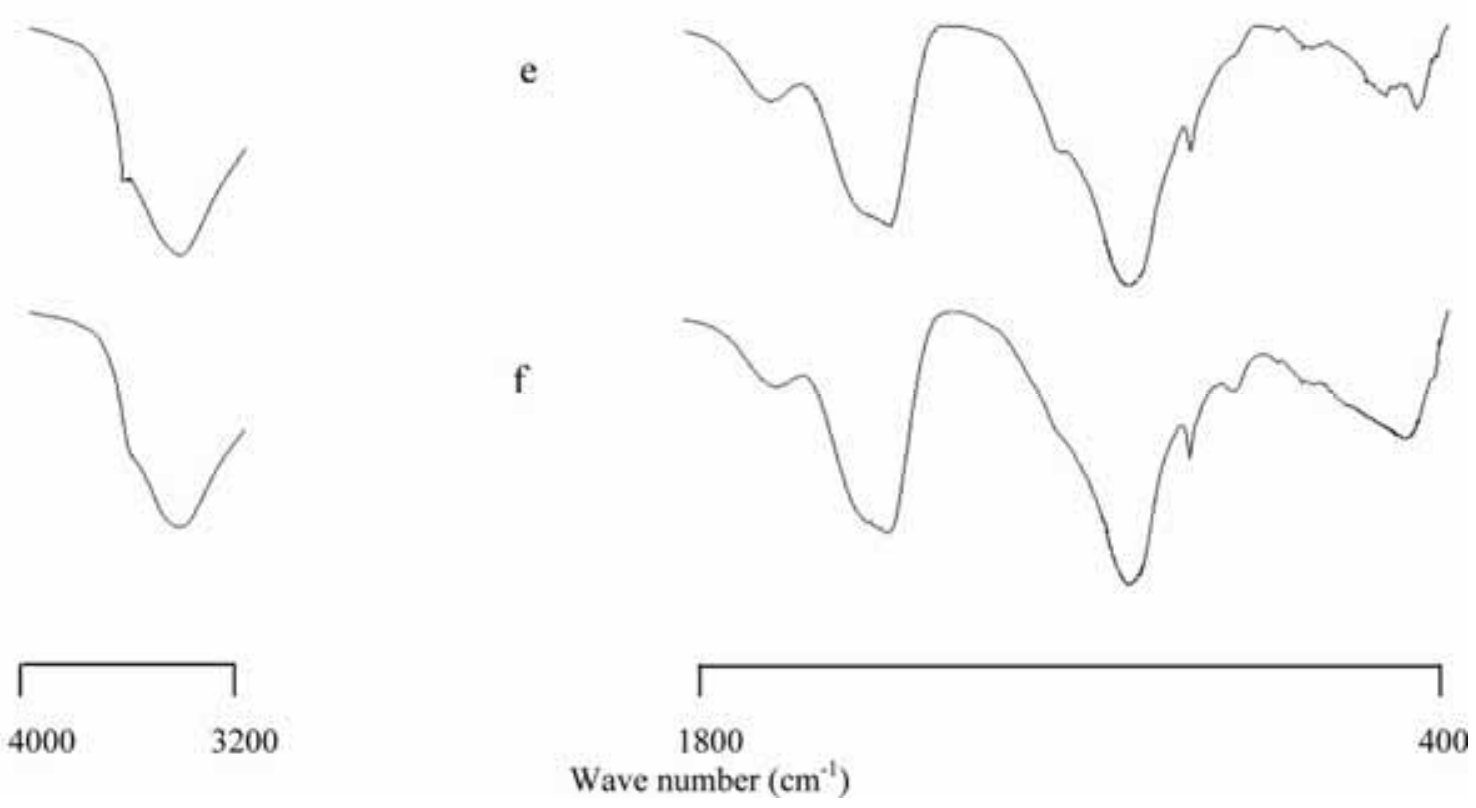

Figure 6. FTIR spectra of SRPC $+30 \% \quad$ hydrated with EW for (a) 1 hour (b) 2 hours (c) 8 hours $\quad$ (d) 1 day (e) 7 days (f) 28 days 